\title{
Gambaran Homosistein pada Pasien Infark Miokard Akut di RSUP Dr. M. Djamil Padang
}

\author{
Ridha Amaliah ${ }^{1}$, Rismawati Yaswir $^{2}$, Tuty Prihandani ${ }^{2}$
}

\begin{abstract}
Abstrak
Berbagai faktor risiko baru telah banyak diteliti, termasuk kadar homosistein total dalam darah. Hiperhomosisteinemia terbukti meningkatkan risiko penyakit kardiovaskular secara independen. Tujuan penelitian adalah mengetahui gambaran homosistein pada pasien infark miokard akut di RSUP Dr. M. Djamil Padang. Penelitian ini merupakan studi deskriptif terhadap 24 orang pasien IMA yang memenuhi kriteria inklusi dan ekslusi serta melakukan pemeriksaan darah di Laboratorium Sentral RSUP Dr. M. Djamil Padang. Penelitian dilaksanakan dari bulan Desember 2016 hingga Agustus 2017. Pemeriksaan kadar homosistein dilakukan di Laboratorium Biomedik Fakultas Kedokteran Universitas Andalas dengan metode ELISA. Hasil penelitian disajikan dalam bentuk tabel distribusi frekuensi. Subjek penelitian terdiri dari 17 orang laki-laki $(70,8 \%)$ dan 7 orang perempuan $(29,2 \%)$. Rerata umur subjek penelitian adalah $56,75(9,34)$ tahun. Faktor risiko tradisional tertinggi adalah merokok $(41,7 \%)$. Rerata kadar homosistein subjek penelitian adalah 25,5(13) $\mu \mathrm{mol} / \mathrm{L}$. Kadar homosistein terbanyak pada pasien IMA adalah hiperhomosisteinemia ringan (54,2\%). Kadar homosistein serum pasien IMA di atas batas nilai normal dengan yang terbanyak adalah hiperhomosisteinemia ringan.
\end{abstract}

Kata kunci:homosistein, infark miokard akut

\begin{abstract}
There are many new risk factors were studied, include total blood homocystein level. Hyperhomocystein was proved to as an independent risk factor that increased cardiovascular disease. The objective of this study was to describe homocysteine profile in AMI patients in Dr. M. Djamil Hospital Padang. This is a descriptive study in 24 AMI patients who meet inclusion and exclusion criteria and were asked to have blood test in Central Laboratory Dr. M. Djamil Hospital Padang. This study was conducted from December in 2016 until August in 2017. Homocysteine level was performed in Biomedic Laboratory Faculty of Medicine Andalas University by ELISA method. Results were describe in distribution and frequency table. Subjects of this study are seventeen male (70.8\%) and seven female (29.2\%). Mean of age is 56.75 (9.43) years. Highest conventional risk factor is smoking (41.7\%). Mean of homocystein level is 25.5(13) $\mu \mathrm{mol} / \mathrm{L}$. Most of AMI patient have mild level hiperhomocysteinemia. Homocysteine level in AMI patient higher than normal range. Most of AMI patient have mild level hiperhomocysteinemia.
\end{abstract}

Keywords: homocysteine, acute myocardial infarction

Affiliasi penulis:1. Dinas Kesehatan Kota/Puskesmas Melur, Pekanbaru. 2. Bagian Patologi Klinik Fakultas Kedokteran Universitas Andalas.

Korespondensi: Rismawati Yaswir,

Email:pdspatklin_pdg@yahoo.com Telp: 081365565633

\section{PENDAHULUAN}

Penyakit kardiovaskular merupakan penyebab utama kematian di seluruh dunia. Penyakit kardiovaskular menyebabkan17,7 juta kematian atau sekitar $31 \%$ dari seluruh penyebab kematian di dunia, 7,4 juta akibat penyakit jantung koroner. ${ }^{1}$ Penyakit 
jantung koroner (PJK) merupakan penyebab terbesar penyakit kardiovaskular, diperkirakan pada tahun 2020 menjadi penyebab utama dari seluruh kematian yaitu sebesar 36\%. ${ }^{2,3}$ Infark miokard akut (IMA) merupakan satu dari lima manifestasi utama penyakit jantung koroner, yaitu angina pektoris stabil, angina pektoris tidak stabil, IMA, gagal jantung, dan sudden death. Sekitar satu juta orang menderita IMA dengan kematian sekitar 450.000 pasien setiap tahunnya di Amerika Serikat. ${ }^{4}$

Infark miokard akut merupakan masalah kesehatan di masyarakat dan penyebab kematian tertinggi di Indonesia. Angka fatalitas kasus atau case fatality rate (CFR) IMA tertinggi dibandingkan penyakit jantung lainnya yaitu $14,1 \%$ pada tahun 2003 berdasarkan statistik rumah sakit di Indonesia. ${ }^{5}$ Penyakit ini menempati urutan ke-9 penyakit rawat inap terbanyak di RSUP Dr. M. Djamil Padang tahun 2016, yaitu sebanyak 504 kasus. $^{6}$ Faktor risiko tradisional berkembangnya aterosklerosis pada IMA adalah hipertensi, diabetes melitus, merokok, kurang aktivitas fisik, dislipidemia, menopause, obesitas. ${ }^{7}$ Hampir sebagian besar penyakit kardiovaskular dapat dicegah dengan menghindari faktor risiko perilaku. Berbagai faktor risiko non tradisional telah diteliti, termasuk kadar homosistein total dalam darah.,

Homosistein adalah asam amino mengandung sulfur, merupakan intermediet pada metabolisme metionin. ${ }^{10}$ Peningkatan kadar homosistein dapat disebabkan karena defek genetik yang menyebabkan defisiensi enzim pada metabolisme homosistein, atau akibat deplesi kofaktor enzim termasuk vitamin sianokobalamin $\left(B_{12}\right)$, asam folat $\left(B_{9}\right)$, dan piridoksin $\left(\mathrm{B}_{6}\right)^{11,12}$

Peningkatan kadar homosistein terbukti meningkatkan risiko penyakit kardiovaskular secara independen. Hasil suatu metaanalisis di Amerika tahun 2002 didapatkan penurunan 25\% konsentrasi homosistein berhubungan dengan penurunan risiko penyakit kardiovaskular. ${ }^{10}$ Prevalensi pasien dengan hiperhomosisteinemia diperkirakan sekitar 5\% pada populasi normal, sedangkan pada penderita aterosklerosis sekitar $13-47 \%$. $^{13}$ Penelitian Chambers dan Kooner di Inggris mendapatkan bahwa kadar homosistein serum merupakan faktor risiko independen penyakit kardiovaskular dan berperan pada peningkatan risiko penyakit kardiovaskular. ${ }^{14}$ Penelitian di Amerika yang dilakukan oleh Humphrey et al, menyimpulkan setiap peningkatan homosistein serum sebesar $5 \mu \mathrm{mol} / \mathrm{L}$ akan meningkatkan risiko penyakit kardiovaskular sekitar $20 \%{ }^{15}$ Penelitian di Gaza oleh Sedo mendapatkan rerata kadar homosistein serum pada pasien penyakit kardiovaskular di atas batas normal. ${ }^{16}$ Penelitian oleh Irawan et al, mendapatkan rerata kadar homosistein meningkat pada pasien jantung koroner dan hiperhomosisteinemia merupakan faktor risiko independen terhadap penyakit jantung koroner pada pasien yang dirawat di Rumah Sakit dr. Sardjito Yogyakarta. $^{17}$

Berdasarkan latar belakang di atas, peneliti tertarik untuk melakukan penelitian tentang gambaran homosistein pada pasien infark miokard akut di RSUP Dr. M. Djamil Padang. Penelitian ini bertujuan untuk mengetahui gambaran homosistein pada pasien infark miokard akut di RSUP Dr. M. Djamil Padang.

\section{METODE}

Penelitian ini adalah studi deskriptif yang dilakukan di Laboratorium Sentral RSUP Dr. M. Djamil Padang, Laboratorium Biomedik Fakultas Kedokteran Universitas Andalas, Bangsal Jantung dan Cardiovascular Care Unit (CVCU) RSUP Dr. M. Djamil Padang mulai bulan Desember 2016 sampai dengan September 2017. Populasi adalah semua pasien yang telah didiagnosis IMA oleh dokter bagian Jantung RSUP Dr. M. Djamil Padang. Sampel penelitian adalah bagian dari populasi yang memenuhi kriteria inklusi; bersedia ikut penelitian dan eksklusi yaitu; pasien yang mendapat terapi asam folat, vitamin $B_{6}$, $\mathrm{B}_{12}$, anti hiperlipidemia, isoniazid, teofilin, karbamazepin, metotreksat, niasin, metformin, pasien dengan penyakit ginjal kronik, pasien dengan penyakit hati kronik, dan mengonsumsi alkohol. Besar sampel berdasarkan rumus besar sampel minimal berjumlah 24 orang.

Data penelitian ditampilkan dalam bentuk tabel distribusi frekuensi 
HASIL

Hasil penelitian terhadap 24 subjek penelitian. Karakteristik subjek penelitian dapat dilihat pada Tabel 1.

Tabel 1. Karakteristik subjek penelitian

\begin{tabular}{|c|c|c|}
\hline Variabel & Rerata (SD) & $n(\%)$ \\
\hline \multicolumn{3}{|l|}{ Jenis Kelamin } \\
\hline Laki-laki & & $17(70,8)$ \\
\hline Perempuan & & $7(29,2)$ \\
\hline Umur (tahun) & $56,75(9,34)$ & \\
\hline \multicolumn{3}{|l|}{ Faktor risiko } \\
\hline \multicolumn{3}{|l|}{ tradisional } \\
\hline Merokok & & $15(41,7)$ \\
\hline Dislipidemia & & $3(8,3)$ \\
\hline Menopause & & $7(19,4)$ \\
\hline Hipertensi & & $7(19,4)$ \\
\hline Diabetes melitus & & $4(11,1)$ \\
\hline
\end{tabular}

Tabel 1 memperlihatkan subjek penelitian terdiri dari 17 orang laki-laki $(70,8 \%)$ dan 7 orang perempuan $(29,2 \%)$. Rerata umur subjek penelitian adalah 56,75(9,34) tahun. Faktor risiko tradisional tertinggi yang dimiliki oleh subjek penelitian adalah merokok $(41,7 \%)$.

Tabel 2. Gambaran homosistein pada subjek penelitian

\begin{tabular}{lll}
\hline Homosistein $(\boldsymbol{\mu m o l} / \mathbf{L})$ & Rerata \pm SD & $\mathbf{n}(\%)$ \\
\hline $5-15$ & & $6(25)$ \\
$>15-30$ & & $13(54,2)$ \\
$>30-100$ & $4(16,7)$ \\
$>100$ & & $1(4,2)$ \\
& $25,5 \pm 13$ & \\
\hline
\end{tabular}

Tabel 2 menunjukkan bahwa subjek penelitian dengan kadar homosistein normal sebanyak 6 orang (25\%), hiperhomosisteinemia ringan sebanyak 13 orang (54,2\%), hiperhomosisteinemia sedang sebanyak 4 orang $(16,7 \%)$, dan hiperhomosisteinemia berat sebanyak 1 orang $(4,2 \%)$. Rerata kadar homosistein subjek penelitian adalah $25,5(33) \mu \mathrm{mol} / \mathrm{L}$.

\section{PEMBAHASAN}

Tabel 1 memperlihatkan bahwa subjek dalam penelitian berjumlah 24 orang dengan jenis kelamin laki-laki $(70,8 \%)$ dan perempuan (29,2\%). Hal ini sesuai dengan penelitian oleh Negandhi et al, meneliti faktor risiko IMA di India mendapatkan prevalensi IMA lebih tinggi pada laki-laki (70\%) dibandingkan dengan perempuan (30\%). ${ }^{18}$ Penelitian lainnya oleh Al-Obaidi et al, tentang peningkatan homosistein pada pasien IMA mendapatkan pasien IMA sebanyak 78\% laki-laki dan $22 \%$ perempuan. ${ }^{19}$ Penelitian oleh Ahmadi et al, yang meneliti epidemiologi IMA di Iran mendapatkan rerata prevalensi IMA lebih tinggi pada laki-laki (72,4\%) dibandingkan dengan perempuan $(27,6 \%){ }^{20}$ Penelitian di Yogyakarta oleh Irawan et al, tentang hiperhomosisteinemia sebagai faktor risiko penyakit jantung koroner mendapatkan pasien IMA sebanyak $82 \%$ laki-laki dan $18 \%$ perempuan. $^{17}$

Infark miokard akut sebagian besar dijumpai pada laki-laki dibandingkan perempuan. Hal ini dihubungkan dengan efek ateroprotektif estrogen pada wanita yang menyebabkan IMA jarang terjadi pada wanita premenopause. ${ }^{21}$ Faktor risiko lain yang bisa memengaruhi adalah kebiasaan merokok pada sebagian besar laki-laki dibandingkan perempuan. ${ }^{22}$

Penelitian ini mendapatkan rerata umur pasien IMA adalah 56,75(9,34) tahun. Hal ini hampir sama dengan penelitian Zhang et al, pada populasi di Cina mendapatkan rerata umur pasien IMA 56,75(8,91) tahun. ${ }^{23}$ Penelitian Al-Obaidi et al, mendapatkan rerata umur pasien IMA 61,8(0,74) tahun. ${ }^{19}$ Insidens IMA meningkat seiring dengan peningkatan umur. Hal ini berhubungan dengan peningkatan faktor risiko pada usia lanjut seperti hipertensi, peningkatan kadar kolesterol serum, diabetes melitus dan aktivitas fisik yang kurang. ${ }^{24}$ Insidens IMA meningkat hingga lima kali lipat pada populasi dewasa umur 40-60 tahun. ${ }^{21}$

Faktor risiko tradisional terbanyak pasien IMA pada penelitian ini adalah merokok (41,7\%). Hal ini sesuai dengan penelitian Batlouni et al, bahwa merokok merupakan faktor risiko tradisional terbanyak pada IMA (61,9\%) dan meningkatkan 2,7 kali risiko penyakit kardiovaskular. ${ }^{25}$ Penelitian di Gaza mendapatkan bahwa penyakit kardiovaskular lebih sering pada individu merokok dibanding yang tidak merokok. ${ }^{16}$ Merokok dapat menyebabkan inflamasi pembuluh darah yang berakibat pada penyempitan pembuluh darah, mengurangi aliran darah serta suplai oksigen ke organ termasuk jantung yang dapat menyebabkan infark miokard. ${ }^{26}$ Merokok menyebabkan trombosis koroner, peningkatan 
pembentukan plak koroner dan destabilisasi plak, aktivasi trombosis, kerusakan endotel serta spasme pembuluh darah koroner melalui peningkatan pengeluaran katekolamin. ${ }^{27}$

Tabel 2 menunjukkan subjek dengan hiperhomosisteinemia ringan terbanyak pada penelitian ini $(54,2 \%)$, diikuti oleh subjek dengan hiperhomosisteinemia sedang $(16,7 \%)$ Hal ini hampir sama dengan penelitian Irawan yang mendapatkan kadar homosistein terbanyak dengan hiperhomosistein tingkat ringan sampai sedang (74\%). ${ }^{17}$ Rerata kadar homosistein subjek penelitian adalah 25,5(13) $\mu \mathrm{mol} / \mathrm{L}$. Hal ini hampir sama dengan penelitian Sedo yang mendapatkan rerata kadar homosistein 22,2(7,0) $\mu \mathrm{mol} / \mathrm{L}^{16}$ Ganguli \& Alam menyatakan kadar ini diklasifikasikan sebagai hiperhomosisteinemia ringan (homosistein $>15-30 \mu \mathrm{mol} / \mathrm{L}$ ). ${ }^{28} \quad$ Peningkatan homosistein serum sebesar $5 \mu \mathrm{mol} / \mathrm{L}$ akan meningkatkan 1,4 kali risiko penyakit kardiovaskular. ${ }^{25}$ Penelitian yang dilakukan Humphrey et al, mendapatkan peningkatan homosistein serum sebesar $5 \mu \mathrm{mol} / \mathrm{L}$ akan meningkatkan risiko penyakit kardiovaskular sekitar 20\%. ${ }^{15}$ Penelitian ini mendapatkan sebanyak enam orang dengan kadar homosistein normal. Hal ini disebabkan adanya faktor risiko lain selain homosistein yang menyebabkan IMA antara lain merokok, dislipidemia, menopause, hipertensi dan diabetes melitus. Enam orang pasien dengan kadar homosistein serum normal, semuanya memiliki faktor risiko yang sama yaitu hipertensi. Hipertensi merupakan faktor risiko independen infark miokard dan merupakan faktor risiko utama penyebab aterosklerosis pembuluh darah koroner. Hipertensi sebagai faktor risiko utama penyakit kardiovaskular menyebabkan satu dari tujuh kematian atau hampir setengah dari seluruh kematian akibat penyakit kardiovaskular di Amerika. ${ }^{29}$

\section{SIMPULAN}

Kadar homosistein serum pasien IMA di atas batas nilai normal dengan yang terbanyak adalah hiperhomosisteinemia ringan (54,2\%).

\section{SARAN}

Perlu dilakukan penelitian lebih lanjut untuk mengetahui hubungan homosistein dan IMA dengan mengeksklusi faktor risiko tradisional.

\section{UCAPAN TERIMA KASIH}

Terima kasih yang sebesar-besarnya kepada semua pihak yang turut membantu hingga selesainya penelitian ini.

\section{DAFTAR PUSTAKA}

1. World Health Organization (WHO). Fact sheet about cardiovascular disease 2015 (diunduh pada Desember 2016). Tersedia dari: http://www.who. int/cardiovascular disease/en/cvd

2. Perhimpunan Dokter Spesialis Kardiovaskular indonesia. Pedoman tatalaksana sindrom koroner akut edisi ketiga (diunduh pada Januari 2017). Tersedia dari: http://www.inaheart.org

3. Gomar FS, Quilis CP, Leischik R, Lucia A. Epidemiology of coronary heart disease and acute coronary syndrome. Ann Transl Med. 2016;4(13): 256-9.

4. American Heart Association. Cardiovascular Disease and Statistics, 2009 (diunduh pada Desember 2016). Tersedia dari: http://www. americanheart.org/presenter

5. Delima, Mihardja L, Siswoyo H. Prevalensi dan faktor determinan penyakit jantung di Indonesia. Bul. Penelit. Kesehat. 2009;37(3):142-59.

6. Pusat Informasi Manajemen RSUP Dr. M. Djamil Padang. Sepuluh penyakit terbanyak rawat inap di RSUP Dr. M. Djamil Padang tahun 2016 (diunduh Mei 2017). Tersedia dari: http://www.rsdjamil.co.id

7. Leal DF, Amorim A, Palmera AC, Castro, Simoes, Ramos AT. Homoscysteine: cardiovascular risk factor in children and adolescents. Rev Assoc Med Bras. 2013;59(6):622-8.

8. Marti-Carvajal AJ, sola I, Lathyris D. Homocystein lowering interventions for preventing cardiovascular events. Cochrane Database of Systemic Reviews. 2015,15(1):1-3. 
9. Shaima C, Moorthi PV, Shaheen NK. Review cardiovascular disease: traditional and non traditional risk factors. Med. Allied Sci. 2016;6(2): 40-51.

10. Ray JG. Elevated homocysteine levels are modestly associated with increased ischemic heart disease and stroke risk. JAMA. 2002;288(16): 2015-22

11. Lievers, Kluitjman, Blom HJ. Genetics of hyperhomocysteinaemia in cardiovascular disease. Ann Clin Biochem. 2003;40(1):46-59.

12. Kumar J, Jayaraman S, Muralidharan N. homocystein a potent modulator. biotechnology and molecular biology review. $2012 ; 7$ (1):1-4.

13. Rosenson RS, Kang DS. Hyperhomocysteinemia, atherosclerosis, and venous thromboembolism. Heart. 2002;10(1):237-478.

14. Chambers JC, Kooner JS. Homocysteine: a novel risk factor of coronary heart disease in UK. Heart. 2001;86(2):121-2.

15. Humphrey LL, Linda L, Rogers K, Freeman M, Helfand M, Fu R. Homocysteine level and coronary heart disease incidence: a systemic review and meta-analysis. Mayo Clin Proc. 2008;83(11):120312.

16. Sedo RR. Homocysteine levels of cardiovascular disease patients attending the cardiac unit at EI Shifa Hospital, Gaza strip. Faculty of Medicine Islamic University of Gaza. 2012:1-103.

17. Irawan B, Sya'bani M, Astoni MA. Hiperhomosisteinemia sebagai faktor risiko penyakit jantung koroner. Jurnal Kedokteran Brawijaya. 2005;21(3):103-11.

18. Negandhi HN, Srikhande SN, Zodpey SP, Ughade SN, Joshi PP. Risk factors for acute myocardial infarction in Central India. Indian $\mathrm{J}$ Community Med. 2015;40(1):19-26.

19. Al-Obaidi MK, Stubbs PJ, Collinson P, Conroy R, Graham I, Mark I. Elevated homocysteine level are associated with increased ischemic myocardial injury in acute coronary syndrome. Journal of the American College of Cardiology. 2009;36 (4):1-6.

20. Ahmadi A, Soori H, Etemed K. Current status of the clinical epidemiology of myocardial infarction in men and women: a national cross-sectional study in Iran. International Journal of Preventive Medicine. 2015;6(1):1-14.

21. Mitchell RN, Schoen FJ. Blood vessel. In: Kumar V, Abbas AK, Fausto N, Aster JC, editors. Robbins and Cotran Pathologic Basic of Disease $8^{\text {th }}$ ed. Philadelpia: Elsevier Saunders. 2010.hlm.542-70.

22. Rains MG, Laney CA, Bailey AL, Campbell CL. Biomarkers of acute myocardial infarction in the elderly: troponin and beyond. Clinical Intervensions in Aging. 2014.2014(9):1081-90.

23. Zhang Y, Huo Y, Chen D, Duo J, Fan F, Jia J. Relationship between plasma homocystein level and lipid profiles in a community based Chines Population. Lipids in Health and Disease. 2017;16 (54):1283-91.

24.Carro A, Kaski JC, Myocardial infarction in the elderly. aging and disease. $2011 ; 2$ (1):116-37.

25. Batlouni M, Taddei, Sarteschi C, Baltar VT, Salvarini, Bertolami. Hiperhomocysteinemia as a risk factor for coronary atherosclerotic disease in the eldery. Arquivos Brasileiros de Cardiologia. 2005;85(3):188-91

26. Husten C. Surgeon General's report-how tobacco smoke causes disease: the biology and behavioral basis for smoking-attributable disease. Centers for Disease Control and Prevention. 2010.hlm.21-2.

27. Glick M. Screening for traditional risk factors for cardiovascular disease. Journal of American Dental Association. 2002;133(3):291-300.

28. Ganguli P, Alam SF. Role of homocysteine in the development of cardiovascular disease. Nutrition Journal. 2015;14(6):1-10.

29.Picariello C, Lazzeri C, Attana P, Chiostri M, Valente S. The Impact of hypertension on patients with acute coronary syndromes. International Journal of Hypertension. 2011;7:1-7. 